\title{
Carotenoid content of underutilized tropical fruits.
}

\begin{abstract}
This study was conducted to evaluate the total carotene content (TCC) and beta carotene (BC) in the selected underutilized tropical fruits. TCC of underutilized fruits estimated by spectrophotometric method was in the range of 1.4-19.8 mg/100 g edible portion. The TCC of these fruits decreased in the order: Jentik-jentik $>$ Durian Nyekak 2>Durian Nyekak 1>Cerapu 2>Cerapu 1>Tampoi Kuning $>$ Bacang 1>Kuini $>$ Jambu Mawar $>$ Bacang 2>Durian Daun>Bacang 3>Tampoi Putih>Jambu Susu. BC contents estimated by HPLC method were highest in Jentik-jentik, followed by Cerapu 2, Durian Nyekak 2, Tampoi Kuning, Durian Nyekak 1, and Cerapu 1, which had a range of $68-92 \%$ of BC in TCC. These underutilized fruits have an acceptable amount of carotenoids that are potential antioxidant fruits.
\end{abstract}

Keyword: Beta carotene; HPLC; Total carotene; Underutilized fruit 